\title{
2003 SONRASI IRAK TÜRKLERINIIN HUKUKİ STATÜSÜ
}

\begin{tabular}{|c|c|}
\hline Makale Bilgisi & ÖZ \\
\hline $\begin{array}{l}\text { Kavramsal Makale } \\
\text { DOI: } 10.35379 / \text { cusosbil.778843 }\end{array}$ & $\begin{array}{l}\text { Yüzyıllardır Irak coğrafyasında yaşayan Türkmenler İngilizlerin Irak’1 işgal etmesiyle } \\
\text { birlikte geri plana itilmiştir. Ülkedeki yöneticiler tarafindan bir tehdit olarak algılanmış }\end{array}$ \\
\hline $\begin{array}{ll}\text { Makale Geçmişi: } \\
\text { Geliş } & 10.08 .2020 \\
\text { Düzeltme } & 18.06 .2021 \\
\text { Kabul } & 30.06 .2021 \\
\end{array}$ & $\begin{array}{l}\text { ve her türlü baskı ve asimilasyon politikalarına maruz kalmıştır. ABD’nin } 2003 \text { yılında } \\
\text { Irak'ı işgal etmesinin ardından Türkmenler için yeni bir umut ışı̆ı belirmiş olsa da } \\
\text { ABD eliyle yeniden yapılandırılan Irak'ta Türkmenlere yine rol biçilmemiştir. } 2003 \\
\text { sonrası Irak'ta yeniden oluşturulan siyasi süreçteki dengeler ve etnik-dinî ayışmalar da }\end{array}$ \\
\hline $\begin{array}{l}\text { Anahtar Kelimeler: } \\
\text { Irak, } \\
\text { Irak Türkleri, } \\
\text { Türkmenler, } \\
\text { Ortadoğu. }\end{array}$ & $\begin{array}{l}\text { Türkmenleri olumsuz etkilemiştir. Nitekim Irak siyasetinde doğrudan rol alamayan } \\
\text { Türkmenler bu süreçte ülke siyasetinde hâkim grupların yanında yer almaya başlamıştır. } \\
\text { Bu ise Türkmenlerin bölünmesine ve ülke siyasetinde etkisizleşmesine yol açmıştır. Bu } \\
\text { Çalışma Türkmenlerin hukuki statüsünü ele almışıtır. Çalışmada Türkmenlerin } 2003 \\
\text { öncesi hukuki durumuna değinilmiştir. } 2003 \text { 'ten sonra Irak'ta yeniden yapılandırılan } \\
\text { siyasi süreçte Irak Türkmenlerinin hukuki statüsü ikinci başlıkta ele alınmıştır. Daha } \\
\text { sonrasında bu statünün Türkmenler üzerindeki etkisi ve yansımaları değerlendirilmiştir. } \\
\text { Çalışma sürecinde Araştırma merkezlerinin Türkmenler hakkında yaptıkları } \\
\text { çalışmalarının yanı sıra, Akademisyenlerin çalışmaları, basın yayın organları ve saha } \\
\text { çalışması sırasında bölgeden elde edilen bilgiler araştırma literatürünün önemli bir } \\
\text { bölümünü oluşturmuştur. Bununla beraber } 2003 \text { sonrasında oluşturulan yeni süreçte } \\
\text { Irak'ta çıkarılan yasa ve yönetmelikler başta olmak üzere Arapça ve Türkçe birçok } \\
\text { kaynaktan yararlanılmıştır. }\end{array}$ \\
\hline
\end{tabular}

\section{THE LEGAL STATUS OF IRAQI TURKS AFTER 2003}

\begin{tabular}{l} 
Article Info \\
\hline Conceptual Article \\
DOI: $10.35379 /$ cusosbil.778843 \\
\hline Article History: \\
Received $\quad 10.08 .2020$ \\
Revised $\quad 18.06 .2021$ \\
Accepted $\quad 30.06 .2021$ \\
\hline Keywords: \\
Iraq, \\
Iraqi Turks, \\
Turkmens, \\
Middle East.
\end{tabular}

${ }^{1}$ Dr. Öğg. Üyesi. Aksaray Üniversitesi, İ̈BF, Uluslararası İlişkiler Bölümü, ziyaabbas@ aksaray.edu.tr, ORCID: 0000-0003-3701-1400. Alıntılamak için/Cite as: Abbas, Z. (2021), 2003 Sonrası Irak Türklerinin Hukuki Statüsü, Çukurova Üniversitesi Sosyal Bilimler Enstitüsü Dergisi, 30 (2), 74-86.

\begin{abstract}
Turkmens who have been living in Iraqi geography for centuries were pushed into the background with the British invasion of Iraq. Turkmens were perceived as a threat by the rulers in the country and were exposed to all kinds of pressure and assimilation policies. Even though a new light of hope appeared for the Turkmen after the USA invaded Iraq in 2003, the Turkmens were not given a role in Iraq, which was restructured by the USA. The balances and ethnic-religious divisions in the political process which re-established in Iraq after 2003 also negatively affected the Turkmen. As a matter of fact, the Turkmens, who could not take a direct role in Iraqi politics, started to take sides with the dominant groups in the country's politics in this process. This has caused Turkmen to be divided and neutralized in the country's politics. This study deals with the Legal Status of Iraqi Turkmens. The legal situation of Turkmens before 2003 was examined in this study. The legal status of Iraqi Turkmens in the political process restructured in Iraq after 2003 has been discussed in the second heading afterwards, the effects and reflections of this status on Turkmen were evaluated. In addition to the studies done by the research centers about the Turkmen during the study process, the information obtained from the region during the studies of academicians, press organs and field work constituted an important part of the research literature. However, in the new process created after 2003, many sources of Arabic and Turkish were utilized, especially the laws and regulations enacted in Iraq.
\end{abstract}


Çukurova Üniversitesi Sosyal Bilimler Enstitüsü Dergisi, Cilt 30, Sayı 2, 2021, Sayfa 74-86

\section{GíRiș}

I. Dünya Savaşında mağlup olan Osmanlı Irak'tan çekilmiştir. Mart 1917'de Bağdat'ı işgal eden İngiltere Kasım 1918'de Irak'ı mandası altına aldığını ilan etmiştir. Bölgenin kaderi büyük oranda 1920'de gerçekleştirilen San Remo ve Paris Konferanslarında belirlenmiştir. Musul Meselesi ise Lozan Antlaşması'nda çözüme kavuşmamıştır. Zira İngiltere, zengin petrol yataklarına sahip olan Musul'u Türkiye'ye bırakmak istememiştir. Musul Meselesinin çözümü için Türkiye ile İngiltere arasında 19 Mayıs 1924'te başlayan müzakereler sonuç vermemiştir. Taraflar, çözüm için, Milletler Cemiyetine, gitmiştir. Sonuçta Milletler Cemiyeti’nin güçlü üyesi olan İngiltere'nin baskısıyla Musul, İngiltere'nin mandası altındaki Irak'a bırakılmıştır. Türkiye, Milletler Cemiyeti'ne üye değildi. Bu kararı da kabul etmemiştir. Fakat 1925'te patlak veren Şeyh Sait İsyanı, Türkiye'yi zor durumda bırakmıştır. Bunun neticesinde Türkiye ile İngiltere arasında 5 Haziran 1926'da Ankara Antlaşması imzalanmıştır.

Anlaşmayla Musul ve çevresi İngiliz mandası altındaki Irak’a bırakılmıştır. Karşılığında Irak hükümeti Musul'dan çıkarılan petrol gelirlerinin \%10’unu 25 yıl süre ile Türkiye’ye verecekti (Güngör, 2014, s. 15). Bu Musul Meselesi'nin Türkiye için, uzunca bir süreliğine kapandığı anlamına gelmekle birlikte Irak Türkmenlerini zor günlerin beklediğinin habercisiydi. Başka bir ifadeyle Ankara Anlaşması, 4 asır boyunca Irak topraklarında yönetici sınıfı olan Türkmenlerin kaderini derinden etkilemiştir. Bundan sonraki yaklaşık 80 yıllık süreçte Türkmenler her türlü baskı, sindirme ve asimilasyon politikasına maruz kalmıştır.

\section{1-2003 Irak Türklerinin Hukuki Statüsü}

1921 yılında Irak kraliyetin kurulmasıyla birlikte İngiliz manda idaresi temsilcisi Perci Cox başkanlığında bir anayasa taslağı hazırlanmıştır.1924 yılında kurucu meclise getirilen taslak metin detaylandırılarak, 123 maddelik bir anayasa hâlini almıştır. Taslak 10 Temmuz 1924 tarihinde kurucu meclis tarafından onaylanmıştır. Ancak petrolün paylaşımı ve Türkiye-Irak sınırının henüz tam olarak belirlenmemiş olmasından dolayı bu metin uzun süre kamuoyuna açıklanmamıştır. Anayasa 21 Mart 1925'te Kral I. Faysal tarafindan onaylanınca halka açıklanmıştır (Silleli, 2005, s. 43).

Irak'ın ilk anayasası olan 1925 anayasasıdır. Irak’ta 1921-1958 yılları arasında süren krallık döneminde kabul edilen veya tadil edilen anayasalarında, Türkmenler dâhil, Araplar dışında, diğer etnik kesimlerle ilgili hiçbir hükme yer verilmemiştir (Demirel, 2000, s. 28). Ancak, 1925 Anayasası'nın 6. maddesinde "Iraklılar arasında, dilleri, ırkları veya inançları ne olursa olsun kanun karşısında sahip oldukları haklar bakımından fark gözetilemez" ifadesine yer verilerek Irak’taki farklı dil, ırk ve inançların varlığı kabul edilmiş ve eşit olduklarının altı çizilmiştir. Söz konusu anayasanın 16. maddesindeki "üyelerin eğitimini sağlamak üzere, bu eğitimin kanunun düzenleyeceği genel programlara uygun olması şartı ile okullar açmak ve idare etmek çeşitli toplulukların hakkıdır" ifadesi ülkedeki etnik ve dinî kesimlere okullar açma ve idare etme hakkı verilmiştir (Demirci, 1989, s. 54). Kayda değer reformlar olmamakla birlikte 1925 anayasası kraliyetin devrilmesine kadar yürürlükte kalmıştır.

3 Ekim 1932 tarihinde İngiliz mandası sona ererken Irak Milletler Cemiyeti'ne üye olmuştur. Manda rejiminin sona ermesi ve Irak'ın, Milletler Cemiyeti’ne kabul edilmesi münasebetiyle 30 Mayıs 1932 tarihinde Irak Başbakanı Nuri Said, bir deklarasyon yayımlamıştır (Turan, 1996, s. 27). Bu deklarasyon Irak’ta Türkmenlerin varlığını kabul eden ilk resmî açıklama olmasının yanı sıra Türkmenlere geniş haklar da tanımıştır.

I. bölümünün 4. ve 5. maddesinde, Irak'taki Türkmen, Kürt, ırk, dil ve din azınlıklarının medeni hakları ve seçimlerde adil bir şekilde temsil edilebilmeleri kabul edilmiştir. Bununla birlikte aynı bölümün 8. ve 9. maddesi ana dilleriyle eğitim öğretim yapabilme, vakıf ve benzeri kurumlar kurup yaşatabilme, basın yayın faaliyetlerinde bulunabilme serbestliği, mahkemelerde kendi dillerini kullanabilmeleri, Türkmenlerin ve Kürtlerin yoğun olarak yaşadıkları bölgelerde bu dillerin de Arapçanın yanı sıra resmî dil olarak tanınması taahhüt edilmiştir. 10. maddede ise deklarasyonda yer alan hükümlerin Milletler Cemiyeti'nin garantisi altında olduğu ifade edilmiştir. Ancak, Irak, iç hukukunda bu deklarasyonda aykırı düzenlemeler yapılmış ve Türk varlığı görmezden gelinmiştir. Başka bir ifadeyle Türkmenlere tanınan bu haklar, her ne kadar güvence altına alınmış gibi görünse de uygulamada büyük sıkıntılar yaşanmıştır (Terzioğlu, 2006, s. 163). Nitekim Türkler üzerinde Arap bilincini yerleştirmek ve asimile etmek için Irak hükümetleri çeşitli politikalar benimsemiştir. Örneğin, Irak Hükümeti 1930-1931 eğitim-öğretim yılında, Kerkük şehir merkezi dışındaki ilkokullarda Türkçe öğretimi yasaklanmıştır. Kerkük’te Türkçe eğitimine yer verilen birkaç okulda ise Türkçe; yabancı bir dil gibi, haftada bir saate indirilmiştir (Saatçi, 1996, s. 204). 1937 yılında Bağdat Yönetimi bunu da kaldırmıştır. Ayrıca, "Türk asıllı memurların Türk bölgeleri dışında çalıştırılmaları, Kerkük ve çevresinde Arap ve Kürt kökenli memur, asker, polis ve jandarmaların kullanılması 1srarla uygulanmıştır”. Bununla birlikte Türkmenlerin 


\section{Çukurova Üniversitesi Sosyal Bilimler Enstitüsü Dergisi, Cilt 30, Sayı 2, 2021, Sayfa 74-86}

yardımlaşma ve sosyal dernekler kurmalarına izin verilmemiştir. Türkmenlerin en yoğun yerleşme merkezi olması sebebiyle Kerkük, yönetimin en çok baskı uyguladığı bir şehir hâline gelmiştir. Hükümet, bu dönemde Türkmen memur ve öğretmenlerini, sistematik biçimde güney Irak bölgesine göndermiştir. Bu uygulamalar 1936 ve 1941 yıllarında da tekrarlanmış ve II. Dünya Savaşı'ndan sonra da devam etmiştir (Demirel, 2000, s. 28-31).

14 Temmuz 1958'de Albay Abdülkerim Kasım liderliğinde yapılan darbeyle kraliyetin devrilmesi ile cumhuriyetin ilan edilmesi Türkmenler için yeni bir dönemin başlangıcı olmuştur. Nitekim 27 Temmuz 1958 tarihli Geçici Anayasa Kürt varlığını kabul ederken Türkmenlerden hiç bahsetmemiştir. Ancak isim vermeden azınlıkların haklarının güvence altında olduğu ifade edilmiştir (Terzioğlu, 2006, s. 164). Dolayısıyla bu dönemde Türkmenlere kendi dillerinde eğitim ve yayın yapma hakkı tanınmıştır. 1 Şubat 1959'da Bağdat Radyosu'nun Türkmence kısmında Türkmen radyosu Türkçe yayın hayatına başlamıştır. 7 Mayıs 1960'ta Türkmen Kardeşlik Kulübü'nün kurulmasına izin verilmiş̧ir. Türkmen Kardeşlik Kulübünün kurulmasıyla Türkmenler sosyal ve kültürel faaliyetlerini organize etme imkânını elde etmiş̧tir (Bağbozan, 2007, s. 52). Ancak Kasım hükümeti, kısa sürede Türkmenlere yönelik uyguladığı politikaları tekrar gözden geçirmiş ve verilen hakları geri almıştır. (Silleli, 2005, s.125-126).

1963-1968 yılları arasındaki Arif Kardeşler dönemi Türkmenler için pek farklı olmamıştır. Türkmenler, Türkçe eğitimi ve birçok sosyal haktan mahrum bırakılmıştır. Ancak önceki dönemlere kıyasla daha iyi bir muamele görmüştür. 1966 yılında Şakir Sabır Zabit tarafından Türkçe ve Arapça "Irak" isimli haftalık bir gazete çıkarılmaya başlanmıştır. Türkmenlerin yaşadıkları bölgelerde sosyal ve kültürel etkinlikler artmıştır. $\mathrm{Bu}$ dönemde ilk defa Ekonomi ve Ticaret Bakanlığı'na Ankara Üniversitesi Ziraat Fakültesi mezunu ve bir Türkmen olan Dr. Nizamettin Arif atanmıştır. Kardeşlik dergisine eski Türkçe'nin yanı sıra yeni Türk Alfabesi ile Türkçe bölüm eklenmiştir. Bir gurup Türk aydını 1968 başlarında İçişleri Bakanlığına müracaat ederek Türkmen Kardeşlik Ocağı doğrultusunda Kerkük'te "Kerkük Kültür Kulübü" isminde bir dernek kurmak için onay istemişlerdir. Ancak 17 Temmuz 1968'de iktidara gelen Arap sosyalist Baas Partisi söz konusu başvuruyu reddetmiş̧ir.

Baas Partisi döneminde Türkmenler sistematik baskı ve asimilasyon politikalarına maruz kalmıştır. 1972 yılından itibaren okullarda Türkçe eğitim ile Irak'ta Türk medyası yasaklamıştır. Bununla birlikte 1980'li yıllarda Türkçe'nin günlük hayatta kullanılması da yasaklamıştır. 1973 yılındaki Geçici Anayasa ve 1990 yılındaki Anayasa'da Türkmenler için herhangi bir maddeye yer verilmemiştir. 1990 anayasasında Irak halkının sadece Arap ve Kürtlerden oluştuğu belirtilmiştir. Bu durum 2003 yllına kadar devam etmiştir (Hasan, 2007, s. 87).

\section{3'ten Sonra Irak Türklerinin Hukuki Statüsü}

2003 sonrası Irak'ın yeniden yapılandırılması sürecinde Geçiş Dönemi Irak Devlet Yönetim Yasası (GDIDYY) çıkarılmıştır. İlk anayasa konumunda olan GDIDYY'nin 53. maddesinin (A) bendi ile 58. maddesi Türkmenler için büyük önem taşımıştır (Hasan, 2007, s. 87). Yasanın 53. maddesinin (C) bendinde, Kerkük'ün özerkliği saklı tutuluyordu. Bu maddede,

Bağdat ve Kerkük hariç olmak üzere, Kürdistan bölgesi dışında bulunan ve sayıları üçü aşmayan herhangi bir vilayetler gurubu, kendi aralarında bir bölge oluşturma hakkına sahip olacaklardır. Bu tür bölgelerin oluşturulmasına ilişskin mekanizmalar Irak Geçiş Dönemi Hükümeti tarafından önerilecek ve incelenerek yasa haline dönüştürülmek üzere, seçimle oluşturulacak Ulusal Meclis'e sunulacaktır. Belli bir bölgenin oluşturulmasına yönelik öneri getiren her türlü yasanın, ulusal meclis tarafından onaylanmasına ilaveten ilgili vilayetlerin halkının katılacağı bir referandum sonucunda kabul görmesi gerekmektedir

ifadesi gereği Kerkük ve Bağdat hariç, Irak Kürdistan Bölgesel Yönetimi sınırları dışındaki diğer iller de kendi aralarında bölge oluşturabilirdi.

Türkmenlerin beklentilerinin aksine GDIDYY'nın 53. maddesinde yer alan Kerkük'ün herhangi bir bölgeye katılamayacağı ifadesine yeni anayasada yer verilmemiştir. Bu ise Kerkük'ün “Kürt federal Bölgesi”ne dâhil edilmesini kolaylaştıracak şekilde uygulanabileceği için endişeleri arttırmıştır. Başka bir ifadeyle bu konuda hayal kırıklığı yaşayan Türkmenler, bu maddenin özel olarak korunmadığı durumunda, Kerkük'ün tüm Irak'ın ortak ve özel bir simgesi olmasını sağlayan özerk statüsünün de ortadan kalkacağını savunmuştur (Çetinsaya \& Özhan, 2009, s. 52). Daha sonra kalıcı anayasanın 140. maddesi olan Anayasa taslağının 138. maddesinde "Yeni Irak Hükümeti kurulduktan sonra Geçici İdari Yasa ve ekini teşkil eden belgeler 53/A ve 58. madde dlşında iptal edilir" ifadesiyle GDIDYY'nin Kerkük ile ilgili 58. maddesinin tüm fikralarının gereğinin yerine getirilmesi şartı da kabul edilmiştir. 58/A-3'e göre, bölgelerinden zorla göç ettirilen ve iş imkânı verilmeyen insanlara 


\section{Çukurova Üniversitesi Sosyal Bilimler Enstitüsü Dergisi, Cilt 30, Sayı 2, 2021, Sayfa 74-86}

hükümet tarafindan iş sağlanacaktır. Buna göre, Saddam Hüseyin döneminde göç ettirilen tüm Kerküklüler, kurulacak komisyonlar aracılığıyla ya eski yerlerine geri dönecek ya da kendilerine tazminat ödenecektir. 58/A4'e göre ise, 2003 'ten önce uygulanan etnik düzeltme politikası çerçevesinde, farklı yöntemlerle resmî kayıtlarda etnik kimliklerini değiştirmeye zorlanan vatandaşlar, gerçek etnik kimliklerini resmî kayıtlarda yeniden yazdırabileceklerdi.

GDIDYY'nin 58/B fikrasında ise, eski rejim döneminde siyasi amaçlar doğrultusunda bazı illerin sınırlarında yapılan düzenlemeler ele alınmıştır. Bu maddede söz konusu sorunun giderilmesi için alternatifler sunulmuştur. 58. maddenin uygulanması yeni yönetimin sorumluluklarından biriydi. Bu maddeye göre, demografik yapının normalleştirmesi, nüfus sayımı ve Kerkük ile tartışmalı bölgelerin geleceği, en geç 31 Aralık 2007'de yapılacak bir referandumla belirlenecekti. (Hasan, 2007, s. 88).

Kalıcı anayasa taslağı 15 Ekim 2005 tarihinde referanduma sunularak kabul edilmiştir. Anayasanın 138. maddesine göre, “yeni Irak hükümeti kurulduktan sonra GDIDYY ve ekini teşkil eden belgeler 53/A ve 58. madde dişında lağvedilecektir." ifadesi yer almıştır. Ayrıca anayasanın 140. maddesi en geç 2007'nin sonunda, referandumla bitecek üç aşamalı bir süreç sonunda, Kerkük ve tartışmalı bölgelerin kaderini belirleyecekti. Bu durum, Kerkük'ün özel statüsünü 2007 sonunda ortadan kaldırarak, Kürt bölgesine dâhil edilmesine imkân verecek şekilde düzenlendiği için Türkmenler başta olmak üzere bütün bölge için büyük bir tehdit oluşturuyordu. Nitekim Kürt gruplar, Kerkük başta olmak üzere, birçok tartışmalı bölgede demografik yapıyı lehlerine dönüştürecek yoğun bir çaba gösteriyordu. Kerkük'te çoğunluğu sağlamak için üç yılda Kürt bölgelerinden 600 bin Kürt kente yerleştirilmiş ve tapu ile nüfus kayıtları tahrip edilmiştir (Tunç, 2007, s. 18). Güven ve huzur ortamının olmadığı ülkede seçmen kütükleri hazırlanmadan silahlı Kürt gruplarının baskısı altında söz konusu referandumda elde edilen sonucun silah zoruyla dayatılma çabasını beraberinde getirebilirdi. Bu ise Kerkük'te etnik çatışmayı daha çok tırmandırma tehlikesi taşıdığı gibi Türkmenlerin soykırım tehlikesine maruz kalabilme endişesine yol açmıştır (Saatçi, 2007, s. 30).

Öte yandan yeni anayasada az da olsa Türkmenlere yer verilmiştir. Anayasa'nın giriş bölümünde “...dostlarımızın ve bizi sevenlerin verdiği uluslararası desteğin ışığında müstebit yönetimin mezhep ayrımcılığına dayalı baskıları neticesinde insanlarımızın eziyet ve acılarını hatırda tutarak, Şii-Sünni, Arap-KürtTürkmen ve geriye kalan diğer bütün kardeş kesimlerden Iraklı şehitlerimizin trajedilerinden ilham alarak..." ifadesi yer almıştır.

Yeni anayasa Türkmenleri, nüfus bakımından çok az olan Asurî ve diğer etnik ve dinî kesimlerle eşit tutularak idari ve kültürel azınlık gibi göstermiştir (Yılmaz, 2006, s. 136). Ancak anayasanın giriş bölümünde, "Şii-Sünni, Arap-Kürt-Türkmen ve geriye kalan diğer bütün kardeş kesimlerden..." ifadesi Türkmenleri, Araplar ve Kürtlerden sonra Irak’ın üçüncü etnik grubu olduğunu dolaylı yoldan vurgulamıştır (Hasan, 2007, s. 91).

Yeni anayasa, 2003'ten önce lağvedilen bazı hakları yeniden gündeme getirmiştir. Anadilde eğitim konusunda, 4. maddenin birinci fikrasındaki, “Arapça ve Kürtçe Irak’ın iki resmî dilidir. Iraklı çocukların, eğitim kuralları dâhilinde resmî eğitim kurumlarında Türkmence, Süryanice ve Ermenice gibi kendi anadillerini öğrenme haklarını veya özel eğitim kurumlarında herhangi bir dilde eğitim görmelerini garanti eder", ifadesi anadilde eğitim ilkesini güvence altına almıştır. Anayasanın 4. maddesinin 4. fikrasında yer alan "Yoğunlukta bulundukları idari birimlerde Türkmence ve Süryanice de diğer iki resmî dildir" ifadesi, Türkmenler için önemli bir husustur. Ancak uygulamanın objektif ölçütlere dayanarak şeffaf olması önem arz etmektedir. Aksi halde, anayasada yer alan hükümlerinin bir anlamı olmaz. Zira Irak Türkmenleri yoğunlukta yaşadıkları bölgelerin kimin tarafindan ve nasıl tespit edilmesi konusunda çekinceleri olmuştur. Ne var ki anayasanın uygulanmasında bu çekinceler önemli ölçüde gerçekleşmiştir (Hasan, 2007, s. 89).

Türkmenlerin idari, siyasi ve kültürel hakları ise anayasanın 122. maddesinde ele alınmıştır. Söz konusu maddede, "Bu anayasa Türkmenler, Keldaniler, Süryaniler ve diğer topluluklar gibi çeşitli milliyetlerin idari, siyasi, kültürel ve eğitim haklarını güvence altına alır. Bu hususlar yasayla düzenlenir” ifadesine yer verilmiştir. Ancak bu hükmün uygulamasında önemli sorunların yaşandığı görülmüştür. Nitekim 2003'ten bu yana Türkmenlere Irak hükümetlerinde yeterli temsil imkânı tanınmadığı gibi yerel yönetimlerde etkileri indirgenmeye çalışılmakta ve bürokraside ilerlemelerinin önüne birçok engel konmaktadır (Hasan, 2007, s. 89).

Türkmenlerin en rahatsız olduğu konu ise Kerkük ve tartışmalı bölgelerle ilgili düzenlemelerdir. Bu konu sadece Türkmenlerin değil ülkenin diğer tüm kesimleri için de en tartışmalı konu olmuştur. Aynı şekilde anayasa taslağının hazırlandığı süreçte ve anayasanın kabulünden sonra da tartışılmaya devam edilmiştir. Söz konusu süreçte Türkmenler, Anayasanın Kerkük’ün özel statüsünü 2007 sonunda ortadan kaldırarak, Kürt bölgesine dâhil edilmesine imkân verecek şekilde düzenlendiğini vurgulamıştır (Hasan, 2007, s. 89). 


\section{Çukurova Üniversitesi Sosyal Bilimler Enstitüsü Dergisi, Cilt 30, Sayı 2, 2021, Sayfa 74-86}

Anayasanın 140. maddesinde Kerkük'ün statüsünün ileride belirleneceği vurgulanmıştır. Bu durum 2007'nin sonunda gerçekleştirilmesi planlanan referandum Kerkük ve tartışmalı bölgelerin nüfus dengesini bozabilecek uygulamalara yol açmıştır. Bununla birlikte söz konusu maddenin uygulamaya konduğu süreçte Iraklı tüm taraflar arasında uzlaşı sağlanamayınca 31 Aralık 2007 tarihinde bu madde zaman aşımına uğramıştır.

Kerkük'ü fiilî olarak elinde bulunduran Kürt siyasi partiler, bu süreçte diğer bölgelerden buraya yoğun bir Kürt nüfusu yerleştirmiş ve bölgenin demografik yapısını önemli oranda değiştirmiş̧ir (Yalçın, 2016, s. 22). Anayasanın 140. maddesinin zaman aşımına uğraması onların planlarını bozmuş olsa da Kürtler Kerkük'ün idari yapısında tekelci bir siyaset izleyerek diğer kesimlere karşı baskı uygulamaya devam etmiştir. 26 Temmuz 2008 tarihinde iller, ilçeler ve nahiyelerle ilgili 36 numaralı kararla birlikte yerel seçimler yasasının 23. maddesi Türkmen, Kürt ve Arap parlamento üyelerinin uzlaşması sonucunda onaylanmıştır. Söz konusu maddenin 1. fikrası gereğince, Kerkük ilinin idaresi, güvenliği ve genel kamu görevlerinin Türkmenler, Kürtler ve Araplar arasında ortak paylaşımı kararlaştırılmıştır. Ancak Kürt siyasetçiler bu kararın uygulanmasını önemli ölçüde sekteye uğratmıştır (Hasan, 2007, s. 90).

2010 genel seçimleri sonrası Irak'ta derinleşen siyasi krizde tarafların Türkmenleri kazanma politikası, Türkmenlerin yararına olmuştur. Nitekim Irak tarihinde ilk kez parlamento, 21 Nisan 2012 tarihinde 37 sayılı Türkmen gündemli özel oturum gerçekleştirmiştir. Söz konusu özel oturumda, Türkmenlerin sorunlarını ve taleplerini içeren bir raporun meclise sunulabilmesi için Kanun Komisyonu, İnsan Hakları, Savunma ve Güvenlik ve Barış komisyonlarından oluşan özel bir komisyon kurulması kararlaştırılmış̧ır. Bu çalışmalar sonucunda hazırlanan rapor, 28 Temmuz'da kabul edilerek bağlayıcı ve kanun kuvvetinde bir karar niteliği kazanmıştır (Semin, 2012).

Karar,

Irak parlamentosu, Türkmenlerin üçüncü ana unsur olduğunu kabul eder; buna dayalı olarak tüm anayasal ve yasal haklarının verilmesini, siyasal, idari, kültürel, eğitim, federal hükümet, federal bölgeler, federal bölge olarak düzenlenmeyen illerde, yerel yönetimlerde, haklarını kullanmalarını sağlayacak gerekli anayasal ve yasal düzenlemelerin yapılması gerektiğini vurgular, Türkmen vatandaşların ihtiyaçlarını karşılamak, köy ve kasabaların imarı, Türkmen sosyal, kültürel, eğitim ve rehabilitasyon kurumlarının kurulması amacı ile Türkmen İşleri Yüksek Kurulu kurularak, federal bütçeden ödenek tahsis edilmesini ve bu amaçla ilgili olarak anayasanın 3. maddesi, 4. maddesinin 4. ve 5. fikraları, 9. maddenin 1-A fikrası, 125., 108., ve 116. maddeleri uyarınca Türkmen Hakları Yasası çıkarılması (Özmen, 2018).

ifadelerini içerdiğinden Türkmenler için büyük önem taşımıştır.

Bu kararda ifade edilen ve anayasanın ilgili maddeleri kapsamında hazırlanan "Türkmen Hakları Düzenleme Yasası",(Kanun Hukuk Ettürkmen, 2017) olarak adlandırılan yasa tasarısı, 17 Eylül 2013'te Bakanlar Kurulu tarafindan onaylandıktan sonra Irak Parlamento'suna sunulmuştur (Özmen, 2013). Ancak tasarı, Parlamento Genel Kurulu'nda 30 Ekim 2013'te yapılan oylamada kabul edilmemiştir. Türkmen siyasetçileri, Türkmenlerin diğer kesimler nezdinde gerekli çalışmaları yapmasına firsat verilmeden, tasarının alelacele parlamentoda oylamaya sunulması sonucunda reddedildiğini savunmuştur. Bununla beraber Kürt milletvekillerinin ret oyu kullanarak, söz konusu tasarıya ırkçı tutumla yaklaştığı görülmüştür (Irak'ta "Türkmen Hakları Yasa Tasarısı" reddedildi, 2014).

2 Aralık 2013'te çıkarılan (45) numaralı Irak Parlamento Seçimleri Yasasının 11. maddesinin 2. şıkkında Hıristiyan, Yezidi, Şebek ve Sabii azınlıkların parlamentoda temsil edilmesi için kota belirlenmiştir. Türkmenlerin de 1srarla kotayla temsil edilme konusunu kabul etmemesi sonucunda çıkarılan bu yasa, Türkmenlerin Araplar ve Kürtlerden sonra Irak'ın üçüncü etnik unsuru olduğunun altını bir kere daha çizmiştir (Irak Resmi Gazetesi 2013).

"Türkmen Hakları Düzenleme Yasası" tasarısını gündemde tutan Türkmenler (Ettürkmen Yutalibune bivizaratin Siyasiyyetin ve İstihtasi Muhafazatey Tellafer ve Ettuz, 2018), 8 Ocak 2018 tarihinde tasarıy yeniden parlamento gündemine aldırabilmiş ve ilk okumaları tamamlanmıştır. Fakat söz konusu yasa tasarısı, Kürtler başta olmak üzere Irak siyasetinde etkili olan kesimlerin, engeline yeniden takılmıştır. Türkmenler bu tutumlara tepki gösterse de sonuç değişmemiştir (Naib Yutalib Biikrar Kanun Hukuk Ettürkmen, 2018).

Türkmenlerin yoğun olarak yaşadıkları IKBY' yasasına da bakmakta yarar vardır. IKBY anayasasına göre, bölge halkı, Kürtler ve Türkmen, Asurî, Keldanî ve Arap azınlıklardan oluşmaktadır. Anayasa 4. maddesinde bu azınlıkların haklarının tanındığı ifade edilmektedir. Anayasanın 7. maddesine göre bu bölgede Kürtçe resmî dildir. Bölgede Kürtçenin yanında Arapça öğretimi de zorunludur. Bununla birlikte Türkmen kültürü için Türkmence, eğitim dili olarak göz önünde bulundurulacaktır. Anayasanın 46. maddesinde IKBY Meclisinde söz 


\section{Çukurova Üniversitesi Sosyal Bilimler Enstitüsü Dergisi, Cilt 30, Sayı 2, 2021, Sayfa 74-86}

konusu azınlıkların adil bir şekilde temsil edilmesine riayet edilecektir. Yine anayasanın 49. maddesinde IKBY Bakanlar Kurulunun oluşturulmasında Türkmen, Asurî ve Keldanîlerin temsilinin dikkate alınacağı da ifade edilmiştir. Ayrıca 66. maddesine göre belediye meclislerinin oluşturulmasında da bu azınlıkların adilane temsili dikkate alınacaktır. Buradaki "adilane" ifadesi, her zaman tartışma konusu olan nüfus unsurunu öne çıkarmaktadır. Ancak Irak Anayasası'nın 121. maddesinde olduğu gibi IKBY Anayasası'nda da bazı kolektif nitelikli azınlık hakları teminat altına alınmakla birlikte, oldukça muğlak ifadeler içermektedir. Kanun koyucu, bu hakkın içeriğini anayasal sınırları belli olmadığı için istediği şekilde doldurabilir (Terzioğlu, 2006, s. 170).

\section{Sonrası Türkmenlerin Temsil Mücadelesi}

Irak'ın yeniden yapılandırılması için savaştan önce 20 Ocak 2003'te kurulan Yeniden Yapılandırma ve İnsani Yardım Bürosu görevlendirilmiştir. Büro'nun başına getirilen Emekli General Jay Garner, 28 Nisan 2003 tarihinde Bağdat’ta gelecekteki hükümeti tartışmak için ulusal bir konferans düzenlemiştir. Bu görevi Garner'dan devralan Paul Bremer, 5 Temmuz 2003'te Irak Geçici Yönetim Konseyi'nin (IGYK) oluşturulduğunu açıklamıştır. Fakat Bremer, konsey kararlarını veto etme yetkisini elinde bulundurmuştur. Bremer'in öncülük ettiği Irak Geçici Yönetim Konseyi 25 kişiden oluşuyordu. Konsey genel itibarıyla Baas Partisi'ne muhalif olan Irak'ın ileri gelen liderlerinden oluşturulmuştur. IGYK'de sadece bir Türkmen'e yer verilirken Başkanlık Komisyonu'nda Türkmenlere temsil hakkı tanınmamıştır (Duman, 2010, s. 56).

Geçici Yönetim Konseyi (GYK)'nin oluşturulması Türkmenlerin dışlandığ1 en önemli gelişme olarak nitelendirilebilir. Zira bu olay daha sonraki yönetimlerde Türkmenlere yer verilmeyeceği anlamına geliyordu (Yılmaz, 2006, s. 136).

Haziran 2004'te İyad Allavi başbakan olarak atanmış ve 33 kişilik Irak kabinesi kurulmuştur. Bakanlar Kurulu'nda Türkmenlere bir bakanlık verilerek, Reşad Ömer Mendan İletişim ve Teknoloji Bakanı olarak atanmıştır. Altyapının tahrip edildiği ve devletin temel ihtiyaçları dahi karşılayamadığı Irak'ta, iletişim ve teknolojiden bahsetmenin mümkün olmadığı bir dönemde Türkmenlere bu bakanlığın tahsis edilmesi dikkat çekicidir. Başka bir ifadeyle Türkmenlere sembolik bir bakanlık verilerek bir taraftan tepkileri azaltılmaya çalışılmış, diğer taraftan ülke yönetiminde pasifize edilmişlerdir.

Türkmenlerin Irak siyasetinde etkileri, ilerleyen süreçlerde de devam etmiştir. 15 Ağustos 2004 'te Bağdat'ta toplanan binden fazla kişi, Irak'ta hükümete danışmanlık yapacak ve denetleyecek geçici meclisi oluşturmak üzere bir araya gelmiştir. Dört gün süren konferans, yoğun pazarlıklar sonunda, geçiş hükümetinin verdiği liste onaylanarak, seçimlere kadar görev yapacak geçici meclisi belirlenmiştir. Konferansta Türkmenler, Hıristiyanlarla birlikte azınlık statüsünde yer almıştır (Duman, 2010, s. 57).

Bununla birlikte Kerkük'teki durum da ABD eliyle Türkmenlerin aleyhine işlemiştir. Kerkük’te güvenlik ve idari görevler başta olmak üzere kilit görevlere Kürtler getirilerek, Türkmenler pasifize edilmiştir. Başka bir ifadeyle ABD Kürtlerin önünü açarak Kerkük'ün geleceğini onların eline bırakmıştır (Duman, 2010, s. 57).

Öte yandan Türkmenler yasama ve yürütme erkinde yer almanın öneminin farkında olarak bu konuda temsil mücadelesine davam etmiştir. Dolayısıyla 2005 yılından itibaren yapılan tüm seçimlere katılmışlardır. Fakat ülkede etkili olan etnik ve mezhepsel ayrışmalar Irak Türkmenlerini de derinden etkilemiştir. Bu nedenle bir bütünlük içerisinde hareket edemeyen Türkmenler, ciddi oranda güç kaybetmiştir (Doğan, 2018, s. 14).

30 Ocak 2005 seçimlerinden sonra uzun pazarlıklar sonucunda yeni hükümet 28 Nisan 2005 tarihinde kurulmuştur. Başbakan olarak belirlenen İbrahim El-Caferi 37 kişilik kabinesinde İmar ve İskân Bakanlığı ile Belediye ve Genel İşler Bakanlığını Türkmenlere tahsis etmiş̧ir. Irak’ta Caferi'nin geçici hükümetinin kurulmasının ardından anayasa çalışmaları başlamıştır. $\mathrm{Bu}$ çerçevede kurulan anayasa komisyonunda Türkmenleri iki üye temsil etmiştir (Duman, 2010, s. 58-61).

30 Ocak 2005 seçimlerinde 9 milletvekili çıkaran Türkmenler, Nuri El Maliki'nin başbakan olarak seçildiği Irak'ın ilk geçici olmayan hükümetinde sadece bir bakanlıkla temsil edilebilmiştir. Gençlik ve Spor Bakanlığı'na Casim Muhammed Cafer atanmıştır. Başka bir ifadeyle Türkmenlere oldukça etkisiz bir bakanlık verilerek dolaylı olarak iktidardan uzaklaştırıldığı görülmektedir (Duman, 2010, s. 58-61). Fakat siyasi mücadeleye devam eden Türkmenler, 7 Mart 2010 seçimlerinde altısı Irak Türkmen Cephesi'nden olmak üzere toplam 10 milletvekili çıkarmıştır. Seçim sonrası oluşan Bakanlar Kurulu'nda üç bakanlık almaları Türkmenler için büyük bir başarı olmuştur (Doğan, 2018, s. 14).

Bununla birlikte Irak Türkmenlerinin baskısı ve siyaset alanındaki etkinliğiyle 2012 yılında Irak Türkmenleri parlamentoda üçüncü millet olarak kabul edilmiştir (Semin, 2012). Türkmenlerin elini güçlendiren bu gelişmeler, Irak siyasetinde pasifize edilmek istenseler de mücadeleye devam ettiklerini göstermesi bakımından önemlidir. 


\section{Çukurova Üniversitesi Sosyal Bilimler Enstitüsü Dergisi, Cilt 30, Sayı 2, 2021, Sayfa 74-86}

30 Nisan 2014'te yapılan meclis seçimlerinde Türkmenler farklı koalisyonlardan toplamda 12 vekil çıkarmışıır. Ancak bu durum, önceki seçimlere göre daha iyi bir performans gösteren Türkmenlerin, bu sayıyla hâlâ ülke genelindeki nüfus oranlarına göre yeterince temsil elde edemediklerini göstermiştir (Abbas, 2010, s. 64). Bununla birlikte Türkmenler, bir önceki Maliki hükümetinde üç bakanlık alırken İbadi hükümeti döneminde ise bir bakanlık almışlardır. İnsan Hakları Bakanlığı, Şii Bedir örgütünden Muhammed Mehdi Bayatlı'ya verilmiştir. İbadi'nin reform hareketleri adı altında ilerleyen dönemlerde bu bakanlığı lağvetmesi, Irak Türkmenlerinden tepki görmesine neden olmuştur (Doğan, 2018, s. 14). Başka bir ifadeyle yasama erkinde temsilini arttıran Türkmenlerin yürütme erkinde etkinlikleri azalmıştır. Bu ise Türkmenlerin Irak siyasetinde yeterince başarılı olmadıklarını göstermiştir. Dolayısıyla verdikleri mücadeleyi yeniden gözden geçirmeleri Türkmenlerin geleceği için önemlidir.

Mayıs 2018'de yapılan genel seçimlerde Türkmenler Kerkük'te 3 sandalye kazanmıştır (Anadolu Ajansı, 2018). Türkmenler, diğer illerde ve farklı listelerde 9 milletvekili daha çıkarabilmiştir. Ancak Türkmenlerin en büyük siyasi kuruluşu olan Irak Türkmen Cephesi Kerkük dışında milletvekili çıkaramaması Türkmen siyaseti açısından dikkat çekici bir durumdur (Duman, 2018).

Yoğun olarak yaşadıkları bölgelerde kullandıkları oyların Kürt partilere kaydırıldığını ve seçimlere şaibe karıştırıldığını savunan Türkmenler (Küzeci, 2018). Kerkük’te protestolar düzenleyerek, (Kekilli, 2018, s. 10) Irak Seçim Komiserliği aleyhine imza kampanyası başlatsa da (Sabah Gazetesi, 2018) sonuç alamamıştır (Irak'ta Elle Yapılan Oy Sayımının Sonuçları Açıklandı, 2918).

Seçim sonuçlarının açıklandığından itibaren Türkmenlerin sürdürdüğü gösteriler etkili olmuştur. Nitekim 1 Temmuz 2018 tarihine kadar geçerliliği olan Irak Parlamentosu, seçim sonuçlarını yeniden görüşmek üzere toplanmış ve seçim sonuçlarına yönelik yoğun itirazlardan dolayı Irak Başbakanlığı tarafindan seçimlerin incelenmesi için bir komisyon oluşturulmuştur. Söz konusu komisyonun hazırladığı rapor 5 Haziran'da parlamentoya sunulmuştur. Raporda seçimlerde yapılan açık usulsüzlükler dile getirilmiştir. Rapor, Ulusal Güvenlik Müsteşarlığı, İçişleri Bakanlığı Polis İşleri ve Güvenlik Komiserliği, kararda Irak Bağımsız Yüksek Seçim Komiserliği (IBYSK), Irak Ulusal İstihbarat Kurumu, Yolsuzlukla Mücadele Heyeti, Federal Mali Denetleme Divanı tarafından ortak bir çalışmayla hazırlanmıştır. 6 Haziran 2018'de 172 milletvekilinin katılımıyla düzenlenen oturumda Irak Parlamentosu oyların yeniden elle sayılmasına yönelik bir karar almıştır. Bununla birlikte Irak dışında kullanılan oylar ile IKBY'de yapılan özel oylama tamamen iptal edilmiştir. Göçmen kampları ve Musul, Diyala, Selahaddin, Anbar vilayetlerinde oy kullanan göçmenlerin oyları ise geçersiz sayılmıştır. Ayrıca kararda Irak Bağımsız Yüksek Seçim Komiserliği'nin IBYSK bazı üyelerinin görevleri dondurulurken, bunların yerine Yüksek Yargı Meclisi tarafından bağımsız hâkimler atanmıştır. Bununla beraber IBYSK'nın vilayet sorumlularının görevleri dondurulmuş ve yerlerine Yüksek Yargı Meclisi tarafından yeni sorumlular görevlendirilmiştir. Ancak bu kararın hemen ardından 9 Haziran'da Bağdat'ta, oyların tutulduğu, IBYSK'ya ait depoda yangın çıkmış ve oyların büyük bir kısmı yanmıştır. Bu ise Irak'taki çıkmazı derinleştirmiş ve seçimlerin yeniden yapılmasına dair düşünceler ortaya çıkmıştır (Duman, 2018).

Irak dışında kullanılan oylar ile IKBY'de yapılan özel oylamanın tamamen iptal edilmesinin yanı sıra göçmen kampları ve Musul, Diyala, Selahaddin, Anbar vilayetlerinde oy kullanan göçmenlerin de oylarının geçersiz sayılması en çok Türkmenleri olumsuz etkilemiştir. Zira Haziran 2014'te patlak veren IŞiD krizinden en çok zarar gören kesim Türkmenler olmuştur. Nitekim Türkmen coğrafyası büyük yıkımların yanı sıra en çok göç veren bölgelerden olmuştur. Bu ise 600 binden fazla Türkmen'i mülteci durumuna düşürmüş̧ür (Duman, 2016, s. 7). Başka bir ifadeyle iptal edilen veya geçersiz sayılan oyların büyük bir kısmının Türkmenlere ait olduğu şüphesizdir. Zira 2014'te 12 milletvekili çıkaran Türkmenler 2018 seçimlerinde sadece 9 milletvekili çıkarabilmiştir. Böylece ülke siyasetinde etkili olanlar, seçim sonuçlarına itiraz eden Türkmenleri cezalandırarak adeta IŞ่iD ile işbirliği yapmıştır. Yeni hükümetin kurulmasına ilişkin süreç ve siyasi pazarlıklar neticesinde diğer taraflar Türkmenleri, Adil Abdulhedi'nin oluşturduğu yeni hükümetin dışında tutmuştur (Irak'taki Türkmen Vekillerden 'Ötekileştirilme' Tepkisi, 2019). Abdulmehdi kabinesinin bağımsız bakanlardan oluştuğu gerekçesiyle hükümetten uzaklaştırılan Türkmenlere yönelik Irak siyasetinde etkisizleştirme eğiliminin sürdürüldüğ̈n̈ü göstermiştir (Zineelabdin, 2020).

Ekim 2019'da Şii nüfusun yoğun olarak yaşadığı bölgelerde başlayan protestolar sonucunda Başbakan Abdulmehedi istifa etmek zorunda kalmıştır (Abdulmehdi istifa etti, 2019). Geçici hükümeti oluşturmakla görevlendirilen Irak Ulusal İstihbarat Kurumu Başkanı Mustafa Kazimî, söz vermesine rağmen, hükümetinde Türkmenlere yer vermemiştir (Yavmun Hazinun Lisiyasiyyi Kerkk fi Bağdad, 2020) Bu ise Türkmenlerin büyük tepkisine neden olmuştur. Konuyla ilgili basın toplantısı düzenleyen Türkmen milletvekilleri Şii gruplarının 


\section{Çukurova Üniversitesi Sosyal Bilimler Enstitüsü Dergisi, Cilt 30, Sayı 2, 2021, Sayfa 74-86}

engeline takıldıklarını ifade etmiş̧tir (Irak Türkmen Cephesi Başkanı Salihi: Bir Siyasi İrade Türkmenlere Bakanlık Verilmesine Karşı Çıktı, 2020).

Bu bağlamda Irak siyasetinde etkili olan kesimlerin küresel ve bölgesel güçlerden destek aldığını söylemek mümkündür. Oysa bu durum Türkmenler için geçerli değildir. Zira Türkmenler Irak ulus devletinin kuruluşundan bu yana hep ülkenin birliği ve bütünlüğünden yana tavır almıştır. Bununla birlikte Türkmenler her zaman Türkiye'nin Irak'taki uzantısı olarak görülmekte ve bu nedenle Irak'a sadakatsizlikle suçlanmaktadırlar. Oysa Türkiye, Irak'taki tüm siyasi kesimlere eşit mesafe gözetleyen denge politikası yürütmektedir. (Duman, 2018). Bu ise, sosyal, kültürel ve ekonomik anlamda Türkiye ile yakın bağ 1 olan Türkmenleri Irak siyasetinde yalnız ve çaresiz bırakmaktadır.

Türkmenlerin kararlı tavrını gören Şii siyasetçilerinin Türkmen seçmenleri kaybetmemek için tutumlarını gözden geçirdikleri söylenebilir. Bu gelişmeler sonucunda Kazimî, Türkmenlere bir devlet bakanlığı verme sözünde bulunmuştur. Irak parlamentosu 6 Haziran 2020'de gerçekleştirdiği oturumda Türkmenlere yeniden oluşturulacak İllerden Sorumlu Devlet Bakanlığı'nın verilmesini kabul etmiştir (Elbarlamanu Yumarriru Muraşşahi Elhakaibil Vezariyyetil Saba Eşşagira ve Yukmilu Hukumetel Kazimî, 2020).

\section{Irak Türklerinin Hukuki Statüsünün Etkisi ve Yansımaları}

2004 yılında Irak anayasası hazırlanırken iki taraf öne çıkmıştı: Şiiler ve Kürtler. Türkmenlerin kaderi "İhtilaflı Bölgeler" adı altında belirlenmiştir. Bu durum, Kürtlerin baskısı sonucunda anayasanın 140. maddesinde ele alınmıştır. Kürtler ihtilaflı bölgeleri Kerkük'ün tamamı; Musul'un Başika, Akra, Sincar, ilçeleri; Selahattin'nin Tuzhurmatu ilçesi ve Diyala'nın da Hanekin ilçesi ile Mendeli olarak tanımlıyordu. Bu madde başta Kerkük olmak üzere neredeyse tüm Türkmen bölgelerini kapsamaktaydı. Bütün ihtilaflı bölgelerde önce normalleştirme sonra nüfus sayımı yapılacak ve 31 Aralık 2007'de de referandumla bölgelerin kaderleri belirlenecekti. (Nakip, 2013, s. 99). Kerkük, Tuzhurmatu, Hanekin, Mendeli, Altunköprü ve Kifri 50 yıl içerisinde demografik yapısı planlı şekilde değiştirilmiş olan Türkmen bölgelerinin kaderi değişmemiştir (Yalçın, 2016, s. 21).

2007 yılında artık Sünniler, siyasi sürece katılmış ve üçüncü güç olarak yer almışlardı. Bu süreçte ihtilaflı bölgeler için belirlenen sürenin sonuna yaklaşılmıştır. Kürtler bölgelerde hemen referandum yapmaktan yanaydı. Şiiler sessizdi; Sünni ve Türkmenler ise bu durumu kabul etmiyordu. Bu süreçte Türkiye'nin de gayretleriyle anayasanın 140. maddesi zaman aşımına uğramıştır. Ancak Irak'ta her hükümet kurma süreci veya siyasi kriz çıktığında Kürt siyasetçiler bu ihtilaflı bölgeleri pazarlık konusu yapmıştır. İlk yıllarda Şii siyasetçiler Kerkük konusunda hep yuvarlak ifadeler kullanmayı tercih etmiştir. Sünni Araplar Kerkük'ün ve diğer ihtilaflı bölgelerin Irak'ın geneline ait olduğunu savunmuştur. Türkmenler ise ihtilaflı bölgelerde esas itibarılyla Türkmenlerin yoğunlukta yaşadığını ve Türkmensiz çözümün olmayacağını ısrarla savunmuştur (Nakip, 2013, s. 99).

Anayasa'nın 140. maddesi işlevini kaybedince, hükümette ağırlı̆̆ı olan Şii Araplar ile ihtilaflı bölgelerde askerî yığınağı olan Kürtler çeşitli manevralarda bulunarak söz konusu ihtilaflı bölgelerde varlıklarını güçlendirmeye çalışmışlardır (Doğan, 2018, s. 15). Bununla birlikte 2003 yllından itibaren Kürtler, Kerkük, Tuzhurmatu, Altunköprü, Kifri, Hanekin ve Mendeli şehirlerine yüzbinleri aşan nüfus kaydırmışlardır. Kürtler, bu bölgelere silahlı Peşmerge ve asayiş güçleri de sevk etmiştir. (Nakip, 2013, s. 101).

Irak'ta 7 Mart 2010 seçimlerinin ardından koalisyon hükümetinin başbakanı olan Nuri El-Maliki, hükümetinde Türkmenlerin en çok temsil edildiği dönemdir (Zineelabdin, 2020). Ancak Maliki, kurduğu hükümeti tamamıyla tek başına kontrol etme ve elinde tutma çabası gütmüştür. Maliki'nin bu çabasından rahatsız olan muhalefete IKBY zemin sağlamış ve öncülük etmiştir. Bununla birlikte 2011 sonunda ABD'nin resmî olarak Irak'tan çekilmesinin ardından, Bağdat'ta meydana gelen siyasi kriz sonucunda oluşan tabloya bakıldığında, Irak’taki Şii-Sünni-Kürt rekabetinde Türkmen faktörünün hissedildiği görülmektedir. Özellikle ITC'nin El-Irakiye listesi içerisinde yer almasının, ülkedeki Türkmen siyasetine kısa vadede faydalı olmuştur (Duman, 2013).

Irak'ta meydana gelen siyasi kriz ortamında tarafların Türkmenleri kazanma politikası, Türkmenlerin lehine olmuştur. Nitekim 21 Nisan 2012 tarihinde Irak parlamentosu, 37 sayılı Türkmen gündemli özel oturumda Türkmenlerin sorunlarını ve taleplerini içeren bir raporun meclise sunulabilmesi için Kanun Komisyonu, İnsan Hakları, Savunma ve Güvenlik ve/veya Barış komisyonlarından oluşan özel bir komisyon kurulmasına karar vermiştir. Parlamento Başkanlık heyeti tarafindan görüşüldükten sonra kabul edilen rapor, 26 Temmuz 2012 tarihinde gündeme alınmış ve 28 Temmuz'da kabul edilmiştir (Semin, 2012). 


\section{Çukurova Üniversitesi Sosyal Bilimler Enstitüsü Dergisi, Cilt 30, Sayı 2, 2021, Sayfa 74-86}

Ancak IKBY ile merkezî hükümet arasındaki kriz sonucunda Nuri El-Maliki'nin 8 Mayıs 2012 tarihinde Kerkük'te Bakanlar Kurulu'nu toplamasının ardından askerî restleşmeyle siyasi kriz derinleşmiştir (Duman, 2013). Maliki'nin beraberinde Kerkük'e giren Irak ordusu Maliki şehri terk ettikten sonra da Kerkük'te kalmaya devam etmiştir. Bunun ardından IKBY de Bakanlar Kurulu'nu burada yapmış ve Irak ordusuna karşı peşmerge güçleri de Kerkük'ün girişine konuşlanmıştır (Nakip, 2013, s. 101).

İki taraf arasında çekişme otorite ve güvenlik boşlukları yaratmıştır. Bu ise en çok Türkmenleri olumsuz yönde etkilemiş̧ir. Her iki taraf da kendi bölgelerini savunurken Türkmenler korumasız kalmıştır. Enerji ve tarım zengini olan Türkmen bölgelerinde 2003 'ten bu yana güvenlik ve göç sorunu yaşanmıştır. Örneğin Aralık 2012'de Kerkük, 14 bombalı saldırı ile sarsılmışıı. Bunun 9'u ağır tahribat yaratmıştır. Saldırıların Musalla, Tisin, El-Vasiti gibi Türkmen mahallelerinde yaşanmış olması da dikkat çekmiştir. Benzer olaylar Tazehurmatu ve Tuzhurmatu gibi Türkmen bölgelerinde meydana gelmiştir (Duman, 2013). Başka bir ifadeyle Bağdat yönetiminin içinde olduğu siyasi krizlerin devam etmesiyle birlikte Bağdat-Erbil hattındaki anlaşmazlık Irak Parlamentosundan Türkmenler lehinde çıkan kararların uygulanmasını engellemiştir (Semin, 2012).

10 Haziran 2014 tarihinde IŞiD Musul'u işgal etmiştir. Bununla birlikte yaşanan gelişmeler sonucunda Musul, Telafer, Muhallebiye, İyaziya, Tuzhurmatu, Süleyman Beg, Yengice, Emirli, Tazehurmatu, Beşir köyü, Karatepe ve Hanekin gibi Türkmen bölgeleri adeta ateş çemberine dönmüştür (Semin, 2014). Telafer, Musul, Tuzhurmatu ve Amirli çevresindeki Yengice, Bastamlı, Çardakl1, Biravcıll, Karanaz gibi birçok Türkmen bölgesini hedef alan IŞiD'in buraları işgal etmesi sonucunda bu bölgedeki Türkmen nüfusu göç etmek durumunda kalmıştır. Başka bir ifadeyle IŞíD saldırıları Irak’taki Türkmen coğrafyasının değişmesine neden olmuştur. Türkmen coğrafyası IŞSỉD ile çatışma hattına dönüşmüştür (Duman, 2016, s. 13).

Türkmen bölgelerinin işgali ve göç Türkmenlerin siyasal birliğini de derinden etkilemiştir. Türkmenlerin maruz kaldığı şiddet ve göçe zorlama sonrasında Şii Türkmenleri Irak'ın orta ve güney bölgelerine, Sünni Türkmenleri IKBY kontrolündeki bölgelere göç etmiştir. Bu durum Türkmenlerin asimile edilmesi yolunda gerçekleşen önemli bir aşama olarak mezhepsel bölünmeyi de derinleştirmiş̧ir (Semin, 2014).

Çatışma sahasına dönüşen Türkmen coğrafyası IŞiD, Peşmerge ya da milis güçlerin kontrolüne geçmiştir. Bu ise Türkmen siyasetçilerinin faaliyet alanı olan bölgelerde örgütlenme ve siyasal yapıyı da derinden etkilemiştir. Göçe zorlanan Türkmenlerin geniş bir coğrafi alana dağılması Türkmenleri örgütlenme konusunda büyük zorluklarla karşı karşıya bırakmıştır (Erkmen, 2017).

IşiD saldırılarını firsat bilen IKBY Mesut Barzani öncülügünde de facto durumu istismar etmiş ve ihtilaflı bölgelerde de jure bir durum yaratmaya çalışmışır. Barzani, Eylül 2017'de bir "bağımsızlık referandumu" düzenlemiş̧ir (Kekilli, 2017). Barzani’nin sözde bağımsızlık referandumunu kabul etmeyen merkezî hükümetin IŞiD sonrası geri alınan bazı Türkmen bölgelerinde yeniden etkili olması buralardaki çatışma ortamının farklı bir boyut almasıyla sonuçlanmıştır. Zira içlerinde PKK terör örgütünün de etkili olduğu bazı Kürt gruplar bu durumu kabullenememiş ve IŞiD militanlarıyla işbirliği hâlinde Kerkük, Altınpörü ve Tuzhurmatu gibi Türkmen bölgelerinde terör faaliyetine devam etmişledir (Reysan, 2018).

\section{SONUC}

Irak Türkmenleri 1921-2003 yılları arasında her türlü baskı ve asimilasyon politikalarına maruz kalmıştır. Türkmenler, 1924, 1937, 1946, 1959 ve 1991 yıllarında birçok katliamla karşı karşıya kalmıştır. Türkmenlere ait birçok yerleşim yeri yok edilmiş ve burada yaşayanlar ülkenin farklı bölgelerine yerleştirilmişlerdir. Araplaştırma politikası çerçevesinde topraklarından göç ettirilen Türklerin yerlerine Araplar yerleştirilmiş̧tir.

ABD işgalinden sonra Irak’ta yeniden yapılandırılan siyaset denklemi Şiiler, Sünniler ve Kürtler üzerinden hesaplar yapılmasından dolayı Türkmenler, iktidar paylaşımından uzak tutulmuştur. Kerkük başta olmak üzere Türkmen coğrafyasının neredeyse tamamı Bağdat-Erbil arasında tartışmalı bölgeler hâline gelmiştir. Dolayısıyla işgal sonrası Irak'ta Türkmenler yeni süreçte ciddi bir varlık mücadelesi vermek zorunda kalmıştır.

Bununla birlikte Türkmenler Irak'taki siyasi atmosferden oldukça etkilenmiştir. Zira Irak'taki mezhepsel kutuplaşmanın etkisi, belirgin bir şekilde Türkmenler üzerinde görülmüştür. Bu ise Türkmenlerin Irak siyasetinde temsil oranlarının düşük olmasına yol açmıştır. Buna rağmen Irak Türkmenleri, ülke siyasetinde mücadeleye devam etmiş̧ir. Türkmenler, Irak siyasetinde etkili olmak için yasama erkinde temsil edilmek için mücadele vermiştir. Söz konusu mücadele sonucunda 2012 yllında Irak Türkmenleri parlamentoda üçüncü etnik kesim olarak kabul edilmiş̧ir.

Öte yandan Bağdat yönetiminin içinde olduğu siyasi krizlerin devam etmesiyle birlikte Bağdat-Erbil hattındaki anlaşmazlık Irak Parlamentosundan Türkmenler lehinde çıkan kararların uygulanmasını engellemiştir. Bağdat-Erbil hattındaki anlaşmazlık güvenlik boşluklarına neden olmuştur. Bu ise en çok Türkmenleri olumsuz 


\section{Çukurova Üniversitesi Sosyal Bilimler Enstitüsü Dergisi, Cilt 30, Sayı 2, 2021, Sayfa 74-86}

yönde etkilemiştir. Her iki taraf da kendi bölgelerini savunurken korumasız kalan Türkmenler faturayı ödemiştir. Bu durumdan yararlanan IŞİD'in Haziran 2014'te Musul'u işgal etmesiyle başlayan kaos sonucunda yüzbinlerce Türkmen nüfusu göçe zorlanmıştır. Türkmen coğrafyası IŞi̇D ile çatışma hattına dönüşmüştür. Türkmen bölgelerinin işgali ve göç Türkmenlerin toplumsal ve siyasal birliğini de derinden etkilemiştir. Bu ise Türkmenlerin siyasi mücadelesini sarsmış ve elde edilen kazanımların uygulanması konusunda büyük bir engel teşkil etmiştir.

Hal böyleyken Türkmenlerin, elde ettikleri yasal hakların uygulanması ve siyasi başarıya ulaşmaları için toplumsal ve siyasal birliklerinin sağlanması gerekmektedir. Bunun yanı sıra göçe zorlanan Türkmenlerin kendi bölgelerine dönmeleri için gerekli yaşam ve güvenlik şartlarının sağlanması büyük önem arz etmektedir. Aynı zamanda Türkmenlerin Bağdat eksenli bir politika izlemesinde fayda vardır. Bununla birlikte BM ve AB gibi örgütler başta olmak üzere uluslararası kamuoyunda destek bulmak için Türkmenlerin daha çok çaba harcaması gerekmektedir. Bu konuda Türkmenlere en büyük desteği verebilecek ve kılavuzluk yapabilecek en önemli ülke Türkiye Cumhuriyeti'dir. Ayrıca Türkiye, insan hakları ve Irak Anayasası çerçevesinde elde edilen hakların uygulanması ve Türkmenlerin diğer etnik gruplarca ezilmesinin önlenmesi için çalışmalarda bulunulabilir. Zira gönülden Türkiye'ye bağlı olan Türkmenlerin Irak siyasetinde güçlenmesi Türkiye'nin bölgedeki etkinlik alanına da yansıyacaktır. Aksi takdirde Türkmenler Irak siyaseti denklemi dışında kalmakla beraber ülkeden silinmeye mahkûm olacaktır. Bu aynı zamanda Türkiye'yi önemli bir toplumsal destekten yoksun kılacak ve Irak'taki etkisini indirgeyecektir.

\section{KAYNAKLAR}

Abbas, Z. (2014). Irak Meclis seçimlerinde Türkmenler kazandı mı?. Ortadoğu Analiz, 6(63), 62-65.

Abdulmehdi istifa etti. (30.11.2019). Yeni Şafak, https://www.yenisafak.com/dunya/abdulmehdi-istifa-etti3516233 (Erişim: 18.07.2020)

Bağbozan, Ş. (2007). Baas yönetimi altındaki Irak Türkleri [Yayımlanmamış Yüksek Lisans Tezi]. Kahramanmaraş Sütçü İmam Üniversitesi.

Çetinsaya, G. \& Özhan, T. (2009). İşgalin 6. yılında Irak. SETA. Pelin Ofset.

Demirci, F. (1989). Irak anayasalarında azınlıklar ve Irak Türkleri. Irak Türkleri Kültür ve Yardımlaşma Demeği.

Demirel, M. (2000). Irak yönetiminde Türkmenler [Yayımlanmamış Yüksek Lisans Tezi]. Gazi Üniversitesi.

Doğan, S. (2018). Irak Türkmenleri (Rapor No. 68). İNSAMER.

Duman, B. (2010). 2003 sonrası Irak siyasetinde Türkmenler ve 2010 seçimleri. Ortadoğu Analiz, 2(16), 53-66.

Duman, B. (2013). IKBY-Irak merkezi hükümeti çekişmesi ve Türkmenlerin durumu. İstihbarat Sahası. https://istihbaratsahasi.files.wordpress.com/2013/01/ikby-irak-merkezi-hkmeti-ekimesi-ve-trkmenlerindurumu.pdf (Erişim: 11.07.2020)

Duman, B. (2016). IŞİD sonrası Türkmenler ve Türkmen bölgelerinin durumu (Rapor No. 203). ORSAM.

Duman, B. (10.07.2018). Irak'ta seçim sonrası siyasi dinamikler ve değişen dengeler. Ufkumuz Haber. http://www.ufkumuzhaber.com/irakta-secim-sonrasi-siyasi-dinamikler-ve-degisen-dengeleranaliz69566h.htm (Erişim: 18.07.2020)

Duman, B. (18.07.2018). 2018 Irak parlamento seçimleri ve sonrası. Dünya Bülteni. https://www.dunyabulteni.net/dubam-ortadogu/2018-irak-parlamento-secimleri-ve-sonrasih425876.html (Erişim: 18.07.2020) 
Çukurova Üniversitesi Sosyal Bilimler Enstitüsü Dergisi, Cilt 30, Sayı 2, 2021, Sayfa 74-86

Elbarlamanu Yumarriru Muraşşahi Elhakaibil Vezariyyetil Saba Eşşagira ve Yukmilu Hukumetel Kazimî. (06.06.2020). Minber Elirak Elhur. http://manber.ch/ArticleShow.aspx=ID257934 (Erişim: 18.07.2020)

Erkmen, S. (14.07.2017), Musul sonrası Irak ve yeni çatışma dinamikleri. Anadolu Ajansl. http://aa.com.tr/tr/analiz-haber/musul-sonrasi-irak-ve-yeni-catisma-dinamikleri-/861287?amp=1 (Erişim: 29.07.2020)

Ettürkmen Yutalibune bivizaratin Siyasiyyetin ve İstihtasi Muhafazatey Tellafer ve Ettuz. (17.09.2018). Almada Paper. https://almadapaper.net/view.php?cat=213284 (Erişim: 18.07.2020)

Güngör, F. (2014). Ortadoğu denkleminde Irak Türkmenleri ve geleceği. Uluslararası Sosyal ve Eğitim Bilimleri, 1(2), 14-43. https://doi.org/10.20860/ijoses.06966

Irak Cumhuriyeti Anayasası. (2008). Mektebetü Essenhuri.

Irak Resmi Gazetesi. (14.01.2004). Geçiş dönemi Irak devleti yönetim yasası (Say1. 3981). https://moj.gov.iq/wqam/3981.pdf (Erişim: 18.07.2020)

Irak Resmi Gazetesi, (02.12.2013). 45 numaralı Irak parlamento seçimleri yasası (Say1. 4300) https://moj.gov.iq/uploaded/4300.pdf (Erişim: 18.07.2020)

Irak'ta "Türkmen Hakları Yasa Tasarısı" reddedildi. (02.11.2014). Anadolu Ajansı. https://www.aa.com.tr/tr/dunya/irakta-turkmen-haklari-yasa-tasarisi-reddedildi/105403 (Erişim: 12.07.2020)

Irak’ta genel seçim sonuçları açıklandı. (19.05.2018). Anadolu Ajansı. https://www.aa.com.tr/tr/dunya/irak-tagenel-secimlerin-kesin-sonuclari-aciklandi/1150981 (Erişim: 18.07.2020)

Irak'ta elle yapılan oy sayımının sonuçları açıklandı. (18.08.2018). NTV. https://www.ntv.com.tr/dunya/iraktaelle-yapilan-oy-sayiminin-sonuclari-aciklandi,1J80pOIuFkms1Sxocr9SFw (Erişim: 18.07.2020)

Irak'taki Türkmen vekillerden 'Ötekileştirilme' tepkisi. (02.07.2019). TGRT Haber, https://www.tgrthaber.com.tr/dunya/iraktaki-turkmen-vekillerden-otekilestirilme-tepkisi-2651744 (Erişim: 18.07.2020)

Irak Türkmen Cephesi Başkanı Salihi: Bir Siyasi İrade Türkmenlere Bakanlık Verilmesine Karşı Çıktı. (07.05.2020). Anadolu Ajansı. https://www.aa.com.tr/tr/dunya/irak-turkmen-cephesi-baskani-salihi-birsiyasi-irade-turkmenlere-bakanlik-verilmesine-karsi-cikti/1831914 (Erişim: 18.07.2020)

Hasan, M. (2007). Dünden Bu Güne Irak Türkmenleri [Yayımlanmamış Yüksek Lisans Tezi]. Gazi Üniversitesi Sosyal Bilimler Enstitüsü, Ankara.

Kanun Hukuk Ettürkmen. $\quad$ (03.08.2017). Iraqi https://arb.parliament.iq/archive/2017/08/03/\%D9\%82\%D8\%A7\%D9\%86\%D9\%88\%D9\%86$\% \mathrm{D} 8 \% \mathrm{AD} \% \mathrm{D} 9 \% 82 \% \mathrm{D} 9 \% 88 \% \mathrm{D} 9 \% 82-$ \%D8\%A7\%D9\%84\%D8\%AA\%D8\%B1\%D9\%83\%D9\%85\%D8\%A7\%D9\%86/؟ (Erişim: 18.07.2020)

Kekilli, E. (17.09.2017). Kuzey Irak'ta bağımsızlık arayışı. SETA. https://www.setav.org/kuzey-iraktabagimsizlik-arayisi/ (Erişim: 18.07.2020)

Kekilli, E. (2018). Irak genel seçimleri Irak’ta yeni bir siyasi kültür arayışı (Rapor No. 239). SETA.

Küzeci, Ş. (26.05.2018). 2018 Irak parlamento seçimleri Kerkük ve Türkmenler. Kerkük Gazetesi. http://www.kerkukgazetesi.com/3871-2/ (Erişim: 18.07.2020) 
Çukurova Üniversitesi Sosyal Bilimler Enstitüsü Dergisi, Cilt 30, Sayı 2, 2021, Sayfa 74-86

Naib Yutalib Biikrar Kanun Hukuk Ettürkmen. (11.01.2018). Alsumaria. https://www.alsumaria.tv/news/226614/\%D9\%86\%D8\%A7\%D8\%A6\%D8\%A8-

$\% \mathrm{D} 9 \% 8 \mathrm{~A} \% \mathrm{D} 8 \% \mathrm{~B} 7 \% \mathrm{D} 8 \% \mathrm{~A} 7 \% \mathrm{D} 9 \% 84 \% \mathrm{D} 8 \% \mathrm{~A} 8-$

\%D8\%A7\%D9\%84\%D8\%A8\%D8\%B1\%D9\%84\%D9\%85\%D8\%A7\%D9\%86-

$\% \mathrm{D} 8 \% \mathrm{~A} 8 \% \mathrm{D} 8 \% \mathrm{~A} 5 \% \mathrm{D} 9 \% 82 \% \mathrm{D} 8 \% \mathrm{~B} 1 \% \mathrm{D} 8 \% \mathrm{~A} 7 \% \mathrm{D} 8 \% \mathrm{~B} 1-$

$\% \mathrm{D} 9 \% 82 \% \mathrm{D} 8 \% \mathrm{~A} 7 \% \mathrm{D} 9 \% 86 \% \mathrm{D} 9 \% 88 \% \mathrm{D} 9 \% 86-\% \mathrm{D} 8 \% \mathrm{AD} \% \mathrm{D} 9 \% 82 \% \mathrm{D} 9 \% 88 \% \mathrm{D} 9 \% 82-$

\%D8\%A7\%D9\%84\%D8\%AA\%D8\%B1\%D9\%83\%D9\%85\%D8\%A7\%D9\%86 (Erişim: 13.07.2020)

Nakip, M. (2013). Irak’ta ihtilaflı bölgeler ve Türkmenler. Ortadoğu Analiz, 5(49), 98-104.

Özmen, H. (18.09.2013). Türkmen hakları düzenleme yasası. Biz Türkmeniz. http://www.bizturkmeniz.com/tr/index.php?page=article\&id=28639 (Erişim: 12.07.2020)

Özmen, H. (08.01.2018). Takrir Havle Vaz ve Matalib Ettürkman. Afkar Hurra. http://afkarhura.com/?p=10238 (Erişim: 12.07.2020)

Reysan, M. (13.12.2017), "Mahavif Min Saytarat Cemaat Errayat Elbeydaa ala Kerkük”, Alquds Al Arabi. http://www.alquds.co.uk/?p=843601 (Erişim: 11.07.2020)

Saatçi, S. (1996). Tarihi gelişim içinde Irak'ta Türk varlı̆̆ı. Tarih Araştırmaları Vakfı.

Saatçi, S. (2007). Irak Türkmenleri ve Kerkük sorunu. Global Strateji, 5(9), 25-34.

Semin, A. (15.09.2012). Irak’taki siyasi çıkmaz, Türkmenler ve Türkiye. Irak Türkleri. http://www.irakturkleri.org/makalegoster.php?makale=68 (Erişim: 12.07.2020)

Semin, A. (21.08.2014). Irak'ta derinleşen IŞiD krizi ve Türkmenler. BİLGESAM. http://www.bilgesam.org/incele/1750/-irak\%27ta-derinlesen-isid-krizi-ve-turkmenler/\#.Wc9b71S0PIU (Erişim: 12.07.2017)

Silleli, T. (2005). 1958'den günümüze Türkiye-Irak İlişikleri [Yayımlanmamış yüksek lisans tezi]. Süleyman Demirel Üniversitesi.

Terzioğlu, SS (2006). Tarihsel süreç çerçevesinde 2005 Irak anayasasına göre Irak Türklerinin hukuksal konumları. Akademik Orta Doğu, 1(1), 159-176.

Tunç, H. (2007). Tarihten bugüne Kerkük ve geleceği. Global Strateji, 5(9), 4-24.

Turan, Ö. (1996). Irak anayasalarında azınlıklar. Avrasya Dosyast, 3(1), 23-36.

Türkmenler Irak seçim komiserliği aleyhine imza kampanyası başlattı. (19.05.2018). Sabah, https://www.sabah.com.tr/galeri/dunya/turkmenler-irak-secim-komiserligi-aleyhine-imza-kampanyasibaslatti (Erişim: 18.07.2020)

Yalçın, E. (2016). Kerkük'ün nüfus yapısını değiştirmeye yönelik çalışmalar. Cumhuriyet Tarihi Araştırmaları, 12(23), 137-166.

Yavmun Hazinun Lisiyasiyyi Kerkk fi Bağdad. (08.05.2020). Kirkuk Now. https://kirkuknow.com/ar/news/62179 (Erişim: 12.07.2020)

Yılmaz, İ. (2006). Geçmişten günümüze Irak’ta Türkmen politikası. Çağdaş Türkiye Tarihi Araştırmaları, 12(1), $127-142$. 
Çukurova Üniversitesi Sosyal Bilimler Enstitüsü Dergisi, Cilt 30, Sayı 2, 2021, Sayfa 74-86

Zineelabdin, A. (11.05.2020). Irak hükümetinde Türkmenlerin temsili sorunu. ORSAM. https://orsam.org.tr/tr/irak-hukumetinde-turkmenlerin-temsili-sorunu/ (Erişim: 12.07.2020) 